\title{
The Neapolitan School: \\ Francesco Durante (1684-1755) - \\ Aspects of Manuscript Dissemination, \\ Misattributions, and Reception
}

\author{
Hanns-Bertold Dietz* \\ The University of Texas at Austin
}

\begin{abstract}
:
After the Austrian conquest of Naples in 1707, Masses, motets and Psalm settings, by Francesco Mancini, Nicola Fago, Domenico Sarro and the then still little-known Francesco Durante, made their way into Bohemia, the Austrian Netherlands, and Saxony. All of Durante's early exported pieces of church music are found in these locations only. From the Zenith of his career, 1738 to 1755, dated manuscripts cover almost every year. The period includes all of the works upon which rests Durante's posthumous fame. During the nineteenth century, his church music, especiallly his works in "Palestrina style," became objects for collectors of "ancient music." The demand for sacred works by Durante and other Neapolitan composers led to misattributions of manuscripts, not always out of ignorance. During the second-half of the nineteenth century, changing attitudes toward church music, the Bach restoration, and the emergence of a view of history tinged with nationalistic overtones led to a change in Durantes's historic position. By 1904, the "Epoch of the Neapolitan School: Leo and Durante, 1725-1766" had been replaced by "The Age of Bach and Handel." The lack of interest in Neapolitan church music that followed led to a neglect of scholarly studies until the second half of the twentieth century, when musicologists began to revive the topic.
\end{abstract}

Keywords: Francesco Durante; Neapolitan School; church music; manuscript dissemination; misattributions; reception.

\footnotetext{
*Hanns-Bertold Dietz (Ph.D., musicology and art history, University of Innsbruck, Austria) is Professor Emeritus of Historical Musicology at the School of Music of The University of Texas at Austin. He is the author of Die Chorfuge bei Georg Friedrich Händel, numerous articles concerning late 17th through early 19th-century music, and contributor to The New Grove Dictionary of Music and Musicians (1st and 2nd ed.), the New Grove Dictionary of Opera, and the encyclopedia Die Musik in Geschichte und Gegenwart (1st and 2nd ed.), particularly concerning 18th-century Neapolitan composers.
} 
When in 1707, during the War of the Spanish Succession, the Neapolitan territories - a possession of the Spanish crown since 1504 - became the property of the Austrian Hapsburg emperor, Naples, a city with two commercial opera houses and four conservatories, was suddenly drawn into the Austrian orbit and brought to the attention of the musical world at large. This new interest, however, was not just focused on Neapolitan opera, but included church music, as well. Actually, the export of Neapolitan music that ensued after 1708 seems to have begun with Neapolitan Kyrie-Gloria Masses, motets, and Psalm settings. Their destination was not Imperial Vienna or the Austrian homeland, but the Austrianruled Kingdom of Bohemia and the Austrian Netherlands. Evidence of this development is provided by the numerous scores and vocal and instrumental parts preserved in the music collections of the Sint-Romboutskathedraal in Mechelen (B-MEaa), the Cathédrale Saint-Michel et Sainte-Gudule in Brussels (B$\mathrm{Bc}, \mathrm{B}-\mathrm{Br}$ ), the St. Vitus Cathedral (CZ-Pak), and the St. Francis Seraphicus Church of the Order of the Knights of the Cross with the Red Star located in Prague (CZPkřiž). Neapolitan church music for the Catholic court church of the Elector of Saxony and King of Poland in Dresden was acquired after 1719, and by way of Prague (D-Dlub). 'The composers, who fulfilled this demand for Neapolitan church music, were the maestros of a new generation of composers: Francesco Mancini (1673-1737), Nicola Fago (1677-1745), Domenico Sarro (1679-1744), and the then relatively little-known Francesco Durante (1684-1766), who had graduated from the Sant' Onofrio conservatory just two years prior to the Austrian conquest of Naples. Dated manuscripts, especially, come from the first two decades of the eighteenth century. Of particular interest here are the following four manuscripts attributed to Durante, dated 1710, 1716, and 1719, found in Mechelen and Prague: ${ }^{2}$

\footnotetext{
1 For B-Bc (Fonds St. Gudule) and B-Br (Fonds St. Gudule) see Bacq (1953) and Lenaerts (1957, vol. 29, 120-125). For CZ-Pak see Stefan (1983-1985, 2 vols.); for CZ-Pkřiž see Renton (1990).

${ }^{2}$ In the following, all manuscripts are identified by library sigla and catalogue numbers, and - where applicable - by the nine-digit source numbers of RISM's thematic database A/II: International Inventory of Musical Sources after1600 (<http:// w.w.w. nisc.com>).
} 
1710: Durante, Motet à 2 "O fortunata dies"

B-MEaa: Sint-Rombouts. Muz. 18. 099 (RISM-A/II: 702.007.091)

Annotation at the end of $\mathrm{vl} 1$ and va parts: Valentino.mag | scrisse | 1710

1716: Durante, Motet à 2 "Exsultate aeterni amores" De/ Sig:re Franc:o

Durante, Neapolitano

CZ-Pkřiž: XXXV E 160 (RISM-A/II: 550.266.994)

Annotation at the beginning of Soprano and organo parts: 1716

1719: Durante, Kyrie-Gloria Mass, Missa Jucunda à 4 in C minor

CZ-Pkřiž: XXXV E 128 (RISM-A/II: 550.266.958)

Title page: 1719, / Del Sigr Durante

: Durante, Motet à 5 "In hac die tam serena"

CZ-Pkřiž: XXXV E 132 (RISM-A/II: 550.266.962)

Title page: 1719 / De/ Sigr Francesco Durante / Neapolitano

These works are significant to us for three reasons: (1) they represent his early years from which we do not have many dated manuscripts; (2) they are not duplicated and preserved anywhere outside the Mechelen, Prague, and Dresden/Leipzig regions; and (3) they come from a period of his life for which we have only very sketchy biographical information at best. ${ }^{3}$ The only other dated manuscript from this time is a score of his 1709 S. I/defonso Mass, possibly an autograph. ${ }^{4}$ Scored for three violins, chorus, and continuo, it still shows proximity to late 17 th-century practices by excluding the words of the intonation and beginning the setting of the Gloria text with et in terra pax. It also "subdivides into sections rather than formal numbers, and contains ensembles à 2 and à 3 , but no solo aria." (Dietz 2001, 741). We do know that Durante in July 1710 was in Naples, where he was hired by the conservatory Sant'Onofrio as its Secondo Maestro, but do not know why he suddenly quit his post just a few months later, on 12 January 1711 . It is safe to say that at the time he was not yet the well-known

${ }^{3}$ Carrer (2002) solves this problem by calling her opening biographical chapter "Vita (immaginaria ma non troppo)," and then charmingly keeps what the title promises.

4 D-MÜs: Sant. Hs. 1389. Missa S.ti Ildefonsi a 5 con V.V. Breve / Fr. Durante per S. Giacomo dei Spagnuoli / - 1709. I| Annotation: [Santini] Dal Sig.r Cavaliere Brondsted a me gentilmente donata / dopo averse fatta una copia. 
teacher-composer with the name recognition he would have twenty years later. There is an inscription on an undated manuscript of a D-major Mass preserved in Prague that reflects this situation: "Del uno Sig:[no]re Neapolitano, Durante" ("By a Neapolitan gentleman, Durante"). Normally, on a title page, the byname "Neapolitan" follows the surname. Here, however, the order is reversed, emphasizing the composer's Neapolitan affiliation.."

We do know that Durante married in 1714. However, the dates of four manuscripts (D-MÜs) that would place them into this time, Sacerdotis Santi 1713, Laudate pueri 1714 and two Beatus vir 1715, all seem to be the result of alterations. ${ }^{6}$ We can only conjecture as to his whereabouts (Rome?) until February 28, 1719, when the Gazetta di Napoli reports that an oratorio (La cerva assetata ovvero L'anima nelle Fiamme desiderosa della Gloria) by the "Virtuoso Maestro di Cappella Francesco Durante" was presented on the preceding Saturday (i.e. 2-181719). ${ }^{7}$ The libretto has survived [I-Nn: 73-A-12(8)]; the music has not.

1719 is also the date given on the cover of a set of eight vocal and instrumental parts of a Missa Jucunda in C minor attributed to Durante and found in the music collection of the Knights of the Cross at Prague. ${ }^{8}$ This collection also holds a bound score of the Mass, here entitled "Gloria à 4." It, too, bears the name of Durante, but does not give the year. ${ }^{9}$ Two additional sets of parts for the Mass are preserved in the archive of the St. Vitus Cathedral in Prague. One set was copied by Krystof Karel Gayer (d. 1734); the provenance of the other is another Prague musician, Antonin Görbig (d. 1737). ${ }^{10}$ A fifth

\footnotetext{
${ }^{5}$ CZ-Pkřiž: XXXV E 130 (RISM-A/II: 550.266.960): Missa./ Exaltationis S. Crucis / à / 5 Voci / Violin: 2. / Viola / Tromba, / Organo e Tiorba / Del uno Sigre. Neapolitano, / Durante.

${ }^{6}$ See Dietz $(1988,131)$.

${ }^{7}$ Griffin $(1993,89)$ : [...]essendo nel Sabato antecedente fatto recitare un devoto Oratorio con scelta Musica composizione del Virtuoso Maestro di Cappella Francesco Durante, esprimendo alle parole con tenerezze: II dolori che soffrono le Anime nelle vive fiamme[...]". [No.] 394, Napoli - 28 Febbraro 1719, Num. 10.

8

CZ-Pkřiž: XXXV E 128 (RISM A/II: 550.266.958).

9 CZ-Pkřiž: XXXV E 129 (RISM A/II: 550.266.959).

10

CZ-Pak: 316a (Gayer); (RISM A/II: 550.269.684).

CZ-Pak: 316b (Görbig); (RISM A/II: 550.269.680).
} 
manuscript copy exists in Leipzig. It is in the handwriting of Johann Sebastian Bach, ${ }^{11}$ an autograph score in which he adds three trumpet parts, and inserts a substitute Christe. Adjusting imported Neapolitan Masses to local customs and conditions was apparently common practice. Both Johann David Heinichen (1683-1729), the Kapellmeister at the Catholic court in Dresden, and his assistant Jan Dismas Zelenka (1679-1745) routinely subjected them to alterations for performances at the Catholic court church. ${ }^{12} \mathrm{~A}$ date and the name of Durante are absent from Bach's score. As to the source Bach may have used to make his copy, we can only assume that the manuscript he borrowed [rented?] came from Prague.

There are, of course, many more undated than dated manuscripts of Masses, motets, and psalms attributed to Durante to be found in Prague, some in multiple copies. For the Messa à 10 Voci in F major, both a score and its vocal and instrumental parts are preserved; ${ }^{13}$ for his Kyrie \& Gloria per Ut Re Mi Fa Sol La à 8 Voci, there are one score and two sets of parts. ${ }^{14}$ The latter is not typical for Durante's Mass settings: It is a double-chorus Mass without any solo numbers, but unified in that the music of the fugal Kyrie from the beginning returns as Cum Sancto Spiritu at the end.

Works preserved in multiple copies can perhaps be viewed as having achieved some level of popularity, like Durante's C-minor Mass mentioned earlier, or his Missa triplicato in Bb major, of which two copies exist in Prague and one in Dresden. ${ }^{15}$ The latter belonged to Jan Dismas Zelenka of the Catholic court chapel in Dresden, and is listed as No. 11 (Missa modestiae) in the inventory of his church music that he started on 17 January 1726 and

\footnotetext{
${ }^{11}$ Schmieder (1956, Anh. 26, 617). See also, Beißwenger (1991, 282-283).

12 See Buzga (1981, 181); Horn (1987, 179-180, 198-199); Bacciagaluppi (2008, 488-497).

${ }^{13}$ CZ-Pkřiž: XXXV E 161 (RISM A/II: 550.266.995), score; CZ-Pkřriž: XXXVI A 45 (RISM A/II: 550.282.574), parts.

${ }^{14}$ CZ-Pkřiž: XXXV C 293 (RISM A/II: 550.255.209), score; Durante, CZ-Pkřiž: XXXV E 131 (RISM A/II: 550.266.961), parts; Durante, CZ-Pak: 320 (RISM A/II: 550.269.686), parts.

15 (Prague) CZ-Pak: 319a (RISM A/II: 550.269.681) and CZ-Pak: 319b (RISM-A/II: 550.269.685); (Dresden) D-Dlub: 2397-D-10. The Dresden manuscript is heavily water damaged and can now be viewed only on microfilm.
} 
continued for more than ten years. ${ }^{16}$ The source for Zelenka's copy obviously must have been one of the two manuscripts in Prague. He could have come across the work in 1723, while he was in Prague for the festivities celebrating the coronation of Emperor Charles VI as King of Bohemia. Could Durante, too, have been present at the event?

Some late eighteenth-/early nineteenth-century authors have stated that Durante travelled to Saxony, Vienna, and Hungary. ${ }^{17}$ Unfortunately, they connect the journeys with names and dates that contradict their claims. However, what if the discrepancies were simply the result of "somebody's inexact recollections of actual events," as has been suggested? (Walker 1954, 819). In other words, what if Durante actually did make such journeys, only earlier on, between February 1719 and October 1728, during the years he seems to have been absent from Naples and biographical information is lacking? He could, for example, have gone to Dresden for the festivities surrounding the wedding of the Electoral-Prince Frederick Augustus of Saxony and the Archduchess Maria Josepha of Austria in September 1719, as Telemann did, and Handel. ${ }^{18}$ He could also have gone to Prague for the coronation of Emperor Charles VI, as Zelenka did. However, there simply is no documentary evidence to prove his presence in these places. Therefore, it is much more important to realize that even if Durante never personally crossed the Alps, his church music did, and was known and performed

\footnotetext{
16 "Kirchenkompositionen von eigener und fremder Hand im Besitz J. D. Zelenkas, 1726" (DDlub: Bibl.-Arch. III HB 787d), inventory reproduced (with commentary) in Wolfgang Horn and Thomas Kohlhase, Zelenka Dokumentation. Quellen und Materialien, 2 vols. (Wiesbaden: Breitkopf \& Härtel, 1989).

17 Vincenzo Manfredini (1788), Pierre-Louis Ginguené (1800), Andrea Mazarella da Cerreto (1814-1818). See Carrer (2002, 35-36).

${ }^{18}$ The Staatsarchiv Dresden, Geh. Cab. Kanzley, Loc. 383. Acta, Die Engagements einiger zum Theater gehorigen Personen u.S.W. betr. ao 1699 -, f. 168, records a special payment made ca. 1720, with the cryptic remark: "Dem Italianischen Violon Francesco, so zur Moritzburg vor S. 'Konigl. Majt. sich hören lassen / 50 Dukaten." Since Durante had studied the violin with Gaetano Francone during his student years at the Sant'Onofrio conservatory, it is tempting to give the reading of this entry a slanted interpretation. However, most likely it refers to Francesco Veracini, who had been at court since 1717. The same folio also lists a payment made to George Frederick Handel, who had been in Dresden for business, namely hiring singers: [f. 168]: "Dem könig: Engl: Capellmeister Händel, welcher vor S.er Königl. Majt: und S.r Hoheit dem Königl. Prinzen sich hören laßen, ein Praesent von | 100 Dukaten." The text of both payment entries is repeated on $\mathrm{f} .193$.
} 
there. From the years 1720-1728, we have only one dated manuscript attributed to him. It is a Kyrie-Gloria Mass in D minor with the date 1724, and the annotation Di Francesco Durante, Copia di Napoli. ${ }^{19}$

By October 1728, the 44 year-old Durante was back in Naples, respected and famous enough to be selected successor of the venerable Gaetano Greco (c1657- c1728) as Primo Maestro of the conservatory Poveri di Gesù Cristo, where he taught until 1739. Among the students he guided there rank Pergolesi, Girolamo Abos, the Spaniard Domenico Terradellas, and the German Joseph Doll. Dated works from this period are more numerous, and include his choruses for Duke Annibale Marchese's Tragedie cristiane (published 1729), the A-minor Litany dated 1731 (I-LANC), his popular "Laudate pueri detto il grottesco," 1732 (D-MÜs), the well-known G-minor Requiem, 27 November 1738 (I-Nf), and his famous Mass in D minor "alla Palestrina," a setting of the complete Ordinary. It is preserved in a Naples' manuscript score with the end annotation "Andrea Famulari à 18 October 1739" (I-Nc), and in over forty copies spread over archives and libraries throughout Europe and the US.

In the autumn of 1739, Durante suddenly resigned from the conservatory dei Poveri di Gesù Cristo. His action immediately had a quasi 'musical chairs' effect: Francesco Feo left his post as first master at the conservatory Sant'Onofrio to succeed Durante at the Poveri, while Leonardo Leo took over from Feo as Primo Maestro at the Sant'Onofrio. Earlier that same year, on 11 June 1739 , Nicola Porpora had been appointed first master of the conservatory Santa Maria di Loreto. ${ }^{20}$ Thus within six months of 1739 , three of the Naples conservatories had changed musical leadership. We do not know why Durante resigned, or his whereabouts for the next three years. Was this perhaps the time during which his rumored sojourns to Germany and Austria could have taken place? There is a unique manuscript attributed to Durante in Vienna (A-Wn: S. M. 16137), an

\footnotetext{
${ }^{19}$ D-MÜs: Sant. Hs. 1394 [a] Chirie / Di Francesco Durante || score (Kyrie only); Sant. Hs. 1394 [b] Canto P.mo Choro / Kyrie et Gloria || parts; Sant. Hs. 1395: Di Francesco Durante 1724.| Cover title: Gloria || Francesco Durante Copia di Napoli, score.

${ }^{20}$ See Dietz $(1972,421-422)$.
} 
"Alma redemptoris mater" for Soprano solo in G minor, dated 1739. It belonged to the repertory of the court chapel of Emperor Charles VI. ${ }^{21}$ Also from the same year, dated "December 1739," comes another "Alma redemptor mater" of Durante. It is a setting for Bass solo and strings, without organ, in Eb major, that has been preserved in several copies in Paris and other places. ${ }^{22}$ After 1800, it gained some popularity through its publication in Pierre-Louis Porro's Collection de Musique sacrèe. Also from 1739, comes the dated autograph of a Salve Regina, a setting for Bass solo, strings, and bassoon ("Con un tocco di fagotti"), dedicated to a "Signor Praun."

It seems to have been around 1740 in Dresden that Zelenka acquired two copies of another work by Durante, a Kyrie-Gloria Mass à 5 in $\mathrm{C}$ major. ${ }^{24}$ Noteworthy here is the fact that - in contrast to his acquisitions during the late 1720s - the copies are now of Italian, not German origin. In addition, there exists in Italy another manuscript of this same Mass, in the music archive of the Basilica SS. Annunziata in Florence, as yet uncatalogued. ${ }^{25}$ It is, therefore, interesting to realize that for all the manuscripts from the first quarter of the eighteenth century that are attributed to Durante in Dresden, Prague, and Mechelen, no originals or duplicates of that time have been found in Naples or elsewhere in Italy. Among the manuscripts from the Cathédrale SaintMichel et Sainte-Gudule in Brussels (now preserved at the library of the Royal Conservatory and the Royal Albert Library), there are some undated motets

\footnotetext{
${ }^{21}$ The court chapel also had two stile antico Masses by Alessandro Scarlatti in its repertory. See Riedel $(1977,69,246-248,271)$.

${ }^{22}$ F-Pc, Gb-Lbl, B-Br, S-Skma.

${ }^{23}$ GB-Lbl: Add. 14.103, f.1r. Title page includes the annotation: "per il Sig.r Praun. "Two copies are preserved in Paris: F-Pc: D.3670 (1) and F-Pc: D.3660.

24

D-Dlub: 2397-D-1, with performance alterations by Zelenka (added Viola part, etc.) and an inserted Credo, not by Durante; and D-Dlub: 2397-D-1a an unaltered copy. See Horn (1987, 180$181,185-189)$. Also concerning this repertory and Mass, see Bacciagaluppi (2008, 489 ff.)

${ }^{25}$ I wish to thank Prof. Francesco Rizzi, Pisa and Florence, for information concerning the existence of the still uncatalogued manuscript in the archive of the Basilica SS. Annunziata in Florence, and for providing me with photo reproductions of selected pages of the manuscript score. The Florence version of the C-major Mass includes violas, unlike the two Italian copies in Dresden (D-Dlub: 2397-D-1 and 2397-D-1a; the viola part in 2397-D-1 was added by Zelenka).
} 
attributed to Durante for which there seem to be no duplicates anywhere else. Perhaps these, too, could be assigned to the period before 1739 :

Durante, Motet, "Ad perennis" à 4, B-Bc: 33766 (RISM-A/II: 702.000.312), parts

Durante, Motet, "Date laudes date honores" à 5, B-BC: 33768 (RISM-A/II:

702.000.314), parts

Durante, Motet, "Amoris alites caelorum" à 4, B-Bc: 33767 (RISM-A/II:

702.000.313), parts; also B-Br: Mus Ms 1379 (RISM-A/II:

700.010.557), parts.

In contrast, the motet "Surge Aurora" from the Fonds S. Gudule at the Royal Albert Library is a copy, for which the original (autograph) is located in the British Library, London. ${ }^{26}$ The same goes for the Durante Missa Solem:[nis] 5 voc., in $\mathrm{F}$ major, at the Royal Conservatory in Brussels (B-BC), for which the dated autograph is also preserved in London (GB-Lbl). ${ }^{27}$ In the case of the D-major Mass attributed to Durante in the Royal Albert Library (B-Br), however, the London counterpart (GB-Lbl) is also a copy. ${ }^{28}$

After a three-year absence, Durante resurfaced in Naples in 1742, and immediately re-established his prominence by becoming Primo Maestro of the Santa Maria di Loreto conservatory (Dietz 1972, 420), replacing Porpora who one year earlier had failed to return from a leave-of-absence in Venice. After the death of Leonardo Leo in 1744, Durante succeeded him at the conservatory Sant'Onofrio. However, when he petitioned the king to make him Leo's successor as Primo Maestro of the Royal Chapel, he was turned down. Instead, Durante and all other applicants had to participate in an open competition held on 21 April 1745. Although Durante did not win the contest, his reputation remained untarnished. As a matter of fact, the motet on the cantus firmus "Protexisti me

\footnotetext{
${ }^{26}$ B-Br: Mus Ms 1621 (RISM-A/ll: 704.002.139) = GB-Lbl: Add. 14.105 (autograph).

27 B-Bc: 33764 (RISM-A/II: 702.000.310) = GB-Lbl: Add. 14. 106, f.7 (autograph): D.O.M. I In afflictionis tempore / Gloria à cinque Voci / Con istrom.ti / 1749 / Di Fran.co Durante. || 28

B-Bc: 33765 (RISM-A/ll: 702.000.311) = GB-Lbl: 14.109.
} 
Deus," which he had to write for the competition, was widely copied during the late eighteenth and nineteenth centuries. ${ }^{29}$ For his late period, from 1742 until his death in 1755, we have dated works, many of them autographs, from every consecutive year, except 1748 and 1755 .

1742: Kyrie-Gloria in G major, parts [incomplete] (GB-Lbl: Add. 14.111, f.1)

1743: Motet Jam videtur, score (GB-Lbl: Add. 14.105, f. 192r)

1744: Confitebor in D, Alto solo, autogr. score, 9 brisr 1744 (GB-Lbl: Add. 14.105, f. 1)

1745: Protexisti me Deus à 5, score, 21 April 1745 (I-Nc: Mus. ms. autogr. 14. 3. 4) [not autograph]

1746: Requiem in C, parts, org. autogr.: Finis 1746 (GB-Lbl: Add. 14.111, f. 128-161r)

1747: Le Quattro stagioni del anno, cembalo, autogr.? (P-Ln; I-Ria: Mss Vess. 284/2, f. 52v $1748-$

1749: Kyrie-Gloria Mass à 5 In afflictionis tempore, in F, score (GB-Lbl: Add. 14.106) Nunc dimittis à 5, score annotation: Canciello minor Scrisse 1749 (GB-Lbl: Add. 14.107)

1750: Litany à 4 in $\mathrm{f}$, autograph. (GB-Lbl: Add. 14.107)

Litany à 4 in g, autogr. (GB-Lbl: Add. 14.107)

1751: Dixit Dominus à 5 in D, score, autogr. (GB-Lbl: Add. 14.104)

1752: Magnificat à 5, autogr. (GB-Lbl: Add. 14.101)

1753: Kyrie-Gloria Mass (“Gloria”), autogr. (GB-Lbl: Add. 14.102)

Salve Regina à 2 Bassi in d (GB-Lbl: Add. 14.104)

Dixit Dominus à 5, score, autogr. (GB-Lbl: Add. 14.101)

S. Antonio da Padova, componimento sacro, libr. (Vn), score (I-Vnm 11420 Mss.It)

1754: Miserere à 5 in c, Per la Chiesa di San Nicolò di Bari, score (GB-Lbl: Add. 14.107) $1755-$

The nine string concertos of Durante are undated, but most probably were composed during the 1740s. They are preserved as two sets of eight concertos, and one set of seven. The set of eight found in Brussels (B-BC), Dresden (D-Dlub), Paris (F-Pc), Naples (I-Nc), and Venice (I-Vc) has the key sequence f, g, Eb, e, A, A, C, A ("La Pazzia"). The second set of eight concertos is preserved in Genoa (I-Gl).

${ }^{29}$ I-Nc: Mus. ms. autogr. 14. 3. 4 [Not an autograph!]. 
It excludes the concerto in $\mathrm{g}$, and substitutes it with a concerto in $\mathrm{Bb}$. The set of seven (F-Pc) excludes both the f-minor and Bb-major concertos.

Durante's famous XII Duetti per Camera for Soprano, Alto, and basso continuo are based on recitatives from solo cantatas (1707) by Alessandro Scarlatti. They most likely are from the 1740 s and not "1720", the date found added in red pencil to the manuscript in the library of the S. Cecilia conservatory in Rome. It is this intriguing and artful set of duet arrangements, or "parodies" as they also have been called (Ferand 1958, 40-64), with which the name Durante has remained associated in the sphere of secular vocal music. More manuscript copies and published editions have been preserved of these duets than any other of his works.

Two late eighteenth-century manuscripts of the XII Duets, found in Rome and London, offer historically interesting arrangements for two sopranos, in which the vocal lines have been embellished and sections of the basso continuo accompaniment have been realized "in the manner of Durante's performance practice." The title of the Rome manuscript (I-Rsc: *G.Ms.302) states: Duetti Per Studio di maniera di cantare $E$ per esercizio di accompagnare al Cembalo Del Sig. r Francesco Durante Per uso Della Sig.ra Teresa Masi. The title page of the London manuscript (GB-Lcm: *181) reads: Duetti per Studio di maniera di cantare, e per Esercizzio d'accompagnare al cembalo del Sig.r Francesco Durante Ridotti nelle sue giuste diminuzzioni secondo L'autore da Gio. Masi, with the end annotation: Finis Laus Deo à di 1 Decembre 1776. Three late eighteenth-century manuscripts of the regular, unadorned version of the 12 duets for soprano and alto are: the "Fitzwilliam 1793" (Gb-Cfm: Mus Ms 97-30-F-6), and two earlier copies, one from around 1750 (D-Hs: M A/826, Prov.: Library Friedrich Chrysander) and the other from circa 1760 (D-Au: HR III 4 1/2 40174).

Until recently, Durante's well-known (6) Sonate per cembalo divisi in studii e divertimenti were considered to have been composed and published "circa 1732," although evidence to the contrary had been available on the dedication 
page from the very beginning. ${ }^{30}$ The date of the publication is now given as "between January 1747 and December 1749," based on the fact that Durante in his dedication of the work to his former student, the Principe d'Ardore, Don Giacomo Francesco Milano, refers to the prince as "Ambassador to France," which he was between 1741 and 1749, and as "Cavaliere di Santo Spirito," which he was named in January 1747 (Magaudda 2001, 15-16)."

The list of students Durante taught after he became Primo Maestro of the Santa Maria di Loreto and Sant'Onofrio conservatories reads like a Who's Who in Italian Opera: Tommaso Traëtta, Pasquale Anfossi, P.A. Gugliemi, Giacomo Insanguine, Niccolò Piccinni, Fedele Fenaroli, Antonio Sacchini, and Giovanni Paisiello. Of these, only Fedele Fenaroli followed Durante's path of teaching and composing church music. Some of the most famous of the former students spared no effort to keep the memory of their teacher alive with laudatory gestures and remarks. Durante's contemporary fame, therefore, did not fade after his death, but it kept growing. It is reported that Sacchini never ended a voice lesson in which he had used Durante's chamber duets without kissing his folio of these works (Burney [1789], 1935, 246). There seemed to have been no doubt for the Italiophile Jean-Jacques Rousseau as to who had been the musical geniuses of the immediate past. "Hurry, go to Naples", he wrote in his Dictionaire de musique (1768), "listen to the masterworks of Leo, Durante, Jomelli, and Pergolesi." (Rousseau, 230). ${ }^{32}$ Leo had been the teacher of Jommelli, and Durante had taught the "divine" Pergolesi.

Performances of his works and their dissemination through manuscript copies also kept Durante's name alive. In Naples, both the Loreto and Sant'Onofrio conservatories continued to perform his music during the second half of the eighteenth and early nineteenth centuries, creating through selection and repetition a repertory of favorites. In October

\footnotetext{
${ }^{30}$ For a reproduction of the dedication page see Pitarresi (1999. 79, III. n. 1)

${ }^{31}$ A copy of the original published edition in Stuttgart (D-SI: K. 124) carries the flyleaf annotation: "Originalausgabe Napoli 1744. Ludwig Gerber, London 1845."

32 "Cour, vole á Naples, écouter les chef-d'oeuvres de Leo, de Durante, de Pergolese."
} 
1770, while visiting Naples, Charles Burney heard a Durante work performed at a local church, and notes in his diary:

Thurs. Oct. 25. After dinner I went once more to hear the boys of St. Onofrio. at the Franciscans church. They performed a Litany that was composed by Durante* [...]

*Durante, who has been dead some years, was a long time Master to the Conservatorio Sant'Onofrio. M. Rousseau's words in speaking of him are very strong: Durante est le plus gran harmoniste d'Italie, c'est à dire du monde. (Dict. est Musique). (Scholes 1959, 258).

Based on dated scores and performance parts preserved today in the library of the Neapolitan conservatory San Pietro a Majella (I-Nc), one can compile the following informative - though probably incomplete - list of a select group of repeat performances in Naples:

Requiem in C minor, parts dated 1750, 1759, 1785 (I-Nc: M.R. 479)

Pastoral Mass in D major, parts 1752, 1779, 1786, 1796, 1800 (I-Nc: M.R. 472)

Requiem in $\mathrm{G}$ minor, parts dated 1756, 1776, 1794; score copies dated 1755, 1787 (I-Nc: M.R. 468)

Te Deum in C major, parts: Naples, Loreto, 6 Agosto 1764 (I-Nc: M.R. 487); Firenze, Agosto 1774 (I-Sd: 2783/2)

Litanie in G minor, parts dated 7bre 25 anno del Sig. 1778 Loreto (I-Nc: M.R. 455); 1785 (M.R. 457)

Litanie in F minor, copy dated 1791 (I-Nc: M.R. 451)

In light of Durante's contemporary and posthumous reputation, the fledgling music historiography and music lexicography of the early nineteenth century could not help but regard Durante as one of the leading masters who guided musical developments between 1725 and 1760. Critical contrary opinions did not hold up under the weight of posthumous esteem. For example, Ernst Ludwig Gerber in the first edition of his Historisch-biographisches Lexikon der Tonkünstler (1790-1792) allotted Francesco Durante only a single paragraph of 20 lines, and in his assessment he quoted Johann Adolph Hasse's statement that "Durante does not deserve the first place; it should be given to Alex. Scarlatti. 
Durante was not only dry, but also baroque.. ${ }^{33}$ In his revised edition of 1812 1814, in contrast, Gerber's entry on Durante had grown to four columns, and instead of Hasse's critical comments it offers the laudations which Rousseau, Reichhardt, Burney, and others had bestowed upon the old master. Above all, Gerber now accords Durante the title of a "creator of the Neapolitan School" of composers (Gerber 1812-1814, col. 960-965). It was this revised view of Gerber which prevailed for much of the nineteenth century, and formed the basis for Raphael Georg Kiesewetter's epoch of "The Neapolitan School: Leo and Durante, 1725-1760," in his Geschichte der europäisch-abendländischen oder unser heutigen Musik, published in $1834 .^{34}$ This historic positioning then was confirmed by Fetis (Kiesewetter 1848), and reiterated in all music lexica from Schilling (1835) through Mendel (1873) to Kornmüller (1891).

Several additional trends emerged during the late eighteenth and early nineteenth centuries which contributed to the fact that Durante's music was not forgotten. First, one had begun to show interest in the music of the past, and started to collect "ancient music." Already before the turn of the century, Johann Friedrich Reichhardt had published and discussed examples from works by Durante and Leo in his Musikalisches Kunstmagazin. With the pride of a discoverer he also presented a choral movement from a Mass by the Neapolitan composer Francesco Feo (1691-1761), praising it as "one of those rare, true art works which reflects neither time nor country" adding that "even the admirers of Handel and Bach could take it for a work of these masters, and others for a work of the greatest Italian composers." (Reichhardt 1791, 122). ${ }^{35}$ During the early nineteenth century the interest in historic music gained full momentum. Dedicated scholars and bibliophiles, such as Giuseppe Sigismondo and Gaspar

\footnotetext{
33 "Durante verdiene nicht den ersten Platz, dieser komme dem Alex. Scarlatti zu. Durante wäre nicht allein trocken, sondern auch baroque gewesen." (Gerber 1790-1792, col. 365).

34 Geschichte der europäisch-abendländischen oder unser heutigen Musik (Leipzig: Breitkopf\&Härtel, 1834).

35 "Eines der seltenen ächten Kunstwerke, denen man kein Zeitalter und Vaterland ansieht[...] daß selbst die Verehrer Händels und Bachs[...] sie eben so gewiß für eine Arbeit dieser Meister, als andere für die Arbeit der größten italiänischen Componisten halte."
} 
Selvaggi (Naples), Fortunato Santini (Rome), Gustav Wilhelm Teschner, Georg Poelschau, Carl von Winterfeld, Ludwig Landsberg (Berlin), Anton Justus Thibaut (Heidelberg), Carl Proske (Regensburg), Aloys Fuchs, and Raphael Georg Kiesewetter (Vienna), who with enormous assiduity gathered and copied thousands of musical manuscripts, particularly of masterworks of the early eighteenth century, greatly contributed not only to the preservation and wide distribution, but also to the availability of works by Durante. ${ }^{36}$

In line with the developing aesthetic viewpoints of the Romantic Movement in Germany, the question "What is genuine church music" surfaced and was hotly debated. ${ }^{37}$ The major complaint became that eighteenth-century church music, including the sacred works of Haydn and Mozart, was "fit more for the opera house than the church." Since it was a well-known fact that Durante had never competed for fame in the operatic arena, but dedicated his career almost exclusively to composing church music, interest in his oeuvre was almost predestined. The collections of "ancient music" published by Choron in Paris, Crotch and Novella in London, Rochlitz in Leipzig, and Commer in Berlin, all included works by Durante, and some of these quickly became favorites in fashionable concerts of historical music. Although the selections made were not truly representative of Durante's works, since they primarily conformed to the aesthetic canon of what one considered to be "genuine" church music, they effectively helped to sustain his position in the historic-aesthetic consciousness of the time. This also afforded him the respect of the Caecilian reform movement of the second half of the nineteenth century, which was so antagonistic toward the church music of Haydn and Mozart. Durante's Missa à la Palestrina as well as his two settings of the Misericordias Domini for eight voices (published in Musica Sacra ca. 1830) became standard fare for better church choirs and choral organizations propagating the resurrection and perpetuation of true church music.

\footnotetext{
${ }^{36}$ The largest collection of Durante manuscripts and autographs is found today at the British Library in London. It was originally put together by the Neapolitan Gaspar Selvaggi (1763-1856) for the Marquess of Northampton who donated it to the British Museum (1843). Selvaggi also had copies made of these volumes which are now in the Bibliothèque nationale, fonds du Conservatoire in Paris (F-Pc).

${ }^{37}$ See Koch (1802, col. 832-833).
} 
A by-product of the interest in Durante, particularly in his Palestrina-style works, was the appearance on the collectors' market of manuscripts with misattributions, even forgeries. One example is the Messa a Capella [sic] à 3 Voci [A, $T, B$, with organ continuo], a setting of the Mass Ordinary in C major assigned to Durante in the Royal College of Music, London (GB-Lcm: Ms. 856). A nineteenth-century manuscript, for which no copies exist elsewhere, it can easily be dismissed as a misattribution on stylistic grounds. Another example is the Missa in C a tre $[\mathrm{T}, \mathrm{T}, \mathrm{B}]$ attributed to Durante. It too is an "a cappella" setting with organ continuo, but not of the complete Ordinary; the Credo is missing. This Mass is preserved in copies by some of the most distinguished collectors of the time, namely Fortunato Santini (D-MÜs: Sant. Hs. 1228), A.F.J. Thibaut (D-Mbs: Mus. ms. 763, f. 12v), Carl von Winterfeld, Rome, 1812 (D-Bds: Mus. ms. Winterfeld 14 , p. 48), A v Harnier, Rome, 1821 (D-F: Mus. Hs. 651), and Carl Proske, Rome, 1834 (D-Rp: Pr-M Durante I/1), and was first published by Franz Krommer in Musica Sacra, vol. II, in Berlin, 1841. Proske, however, after having studied the Mass in greater detail, suddenly had strong doubts about its authenticity, which he expressed in a hand-written note that he attached to the score in his Regensburg library:

This 3-voiced vocal Mass, well-known to collectors under Durante's name, is all too suspect to seriously consider it any longer to be a work by Francesco Durante. [...] Out of respect for excellent authors and as a warning to all future collectors, one should identify these kinds of works and trace their origin. This Mass in particular, exhibiting not the slightest characteristics of Durante's mastery, seems almost nothing but a clumsy attempt to use this great name.

It was during the mid-nineteenth century that voices criticizing the Neapolitan School began to surface and gain momentum. The cause was firmly rooted in a growing nationalistic fervor that even affected how Germans and

\footnotetext{
38 "Diese den Sammlern unter dem Namen Durante's bekannte 3stimmige Vokalmesse ist allzu verdächtig um noch länger im Ernst für ein Werk von Francesco Durante gehalten werden zu können. [...] Dergleichen Werke sollte man zur Ehre ausgezeichneter Verfasser und zur Warnung künftiger Sammler hervorsuchen und ihrer Entstehung nachforschen. Namentlich erscheint diese Messe, ohne den kleinsten Charakterzug der Meisterschaft Durantes an sich zu tragen, fast wie ein plumpes Pasquill auf diesen großen Namen." Note (without date) in the handwriting of Dr. Carl Broske, attached to the manuscript: D-Rp: Pr-M Durante I/1 (Regensburg).
} 
Italians viewed music history. Friedrich Chrysander, for example, argued in his Handel biography of 1858, "Up to the present day, it has been essentially the Neapolitan-Italian way in which we look at music history, and therefore it still offers a distorted view." And with a backward glance at Kiesewetter's epochs, he further decreed, "The elevated course of the development of music does indeed lead through Al. Scarlatti, but not through the Neapolitan school; this would only be the case if Handel had belonged to it instead of Leo, Durante, and Hasse." (Chrysander 1858, 233). ${ }^{39}$ The break-up of the traditional perception of history was hurried along by the Bach restoration which, in the ultimate sense, was a German national heritage movement. It not only helped to reshape the history of the eighteenth century from a German viewpoint, it also led to the formation of new aesthetic norms and critical values which, when rigorously applied, did not favor the Neapolitan accomplishments. One began to talk about Durante's vocal music as written in Schnörkelstil. Although the term basically meant "embellished or coloratura" style, common to late baroque music, it conveyed a solidly negative meaning. The same manner of writing when found in J. S. Bach, however, was judged differently because, as one critic put it, his works are "in spite of all that often quite expressive." Similarly, the typical running basses of the baroque style with their continuous rhythm, when encountered in Durante were considered "monotonous" and "tiring," but when occurring in Bach they were judged "interesting" because of "the additional contrapuntal richness." ${ }^{40}$ The very compositional aspects which had been central to Scheibe's famous criticism of Bach, now served as the basis for criticizing that music in which they were missing. Bach's contrapuntal complexity became a basis for value judgment.

Perusing the late nineteenth-century historiographic writings one cannot help but get the distinct impression that there was a subtle, but in the end quite

\footnotetext{
39 "Bis auf den heutigen Tag ist es wesentlich die neapolitanisch-italienische Betrachtung mit der wir in die Musikgeschichte blicken, und so befindet sich diese noch immer[...] in einer schiefen Stellung[...] In der Entwicklung der Musik geht die Höhenrichtung allerdings durch Al. Scarlatti, aber nicht durch seine Schule, durch diese würde sie nur gehen, wenn Händel darin gewesen wäre, statt Leo, Durante und Hasse." 40

Carl von Bruyck, Allgemeine musikalische Zeitung, no. 6, 1872, cited in Langhans (1882, 257-258).
} 
effective, campaign at work aimed at discrediting and undermining the reputation of the Neapolitan masters, historically as well as aesthetically. Hasse's critical characterization of Durante as being "trocken" resurfaced, and so did remarks claiming that by basing his famous chamber duets on recitatives of Alessandro Scarlatti, he had opened himself up to the suspicion of "lacking in invention of beautiful melodies." (Gerber 1812-1814, col. 963). This suspicion, caused by a loss of understanding and appreciation for baroque parody practice and ars inveniendi, soon was accepted as a quasi-fact. This is made obvious by John Hullah's statement (1865) that Durante is "perhaps more remarkable for his treatment of subjects than his invention of them," although he added, "the elegance of his part-writing, his skill in instrumentation, and, more than all, the sustained dignity of his style, make large amends for the want of inventiveness sometimes complained of in his music." (Hullah 1865, 65). For Wilhelm Langhans in 1882, the former suspicion of a "want of inventiveness" had finally become a basic "lack of genius," which he considered to be only more immediately apparent in Durante's duets than in his church music. He criticized Durante's Magnificat in B-flat major, which had become quite popular in editions by C.F. Rex and Robert Franz, as "not entirely free of weaknesses." (Langhans, 257-258). To prove his point, he cites the first six measures of its Tenor-Bass duet "Suscepit Israel." Not everyone agreed with his assessment. Hermann Kretzschmar (1888, 296), for example, praised the work as "the ideal setting of the Marian Song of Praise," and the very same duet as its most "down-to-earth side." For the Viennese critic and historian Eduard Hanslick Durante's Magnificat in B-flat major was "a tone poem [Tondichtung] that in the beauty of religion celebrates the religion of beauty." $(1892,285)$. Such opinions, however, did not stem the tide.

Other influences which led to the erosion of the traditional historic view came from the Palestrina renaissance and the liturgical restoration of the Catholic Church, endeavors which in 1903 climaxed in the first scholarly edition of the works of Palestrina through F. X. Haberl and the Motu Proprio of Pope Pius X. Although Durante, particularly by virtue of his works in stile antico, had been hailed as master of true and genuine church music, he was 
now criticized on the very basis of these works. Disregarding the historic-stylistic differences and nature of the early eighteenth-century concept of stile antico, one began to examine them by comparison with the Palestrina model and considered them to be unsuccessful imitations. Commenting on Durante's Missa alla Palestrina, Langhans $(1882,256)$ concluded that it was "far removed from the purity and sovereign freedom of musical design of a Palestrina." ${ }^{41}$ Forty years later, Karl Gustav Fellerer (1929), in the first important study of stile antico in eighteenth-century church music, is still critical of Durante for showing "little feeling for Palestrina's intrinsic style characteristics" and for opening the door to contemporary innovations that should have no place in such music. (Fellerer, 130).

In the end, it was the Motu Proprio, which, by withdrawing the liturgical and functional basis from the instrumentally accompanied church music of Durante, proved to be the keystone that capped the process of historic repositioning. No longer having the official sanction of the Catholic Church, performances of Neapolitan sacred music became dependent on a place in the concert hall, where, in light of the new aesthetics, it did not survive the competition with Bach and Handel. As a result, the music of once celebrated masters lost its stature and was condemned to an existence in the vaults of research libraries. By 1904, Kiesewetter's Epoch of Leo and Durante had officially become Fuller-Maitland's Age of Bach and Handel (Fuller-Maitland 1904).

The after-effect of these developments is reflected particularly in the German and English music historiography of the early twentieth century. Although the expression "Neapolitan School" was not abandoned, it gradually acquired a thoroughly negative connotation. One spoke of the "Herrschaft der neapolitanischen Schule," (Schering 1924) implying dictatorship, not merely dominance. As far as church music was concerned, the Neapolitans were held responsible for the "rapid descent from glorious heights," blaming them for having planted the seeds of the "sacred style modeled on opera" that caused the

\footnotetext{
$\overline{41}$ "Weit entfernt von der Reinheit und souveränen Freiheit der Tongestaltung eines Palestrinas."
} 
decline (Abert 1919, 297-299). Isolated attempts at repudiating the negative viewpoints had little impact on the general consensus. ${ }^{42}$ The consequence for musicology was a general disinterest in Neapolitan composers and their works unless they could be linked directly to the Bach-Handel, Haydn-Mozart, and German-Austrian spheres. As a result, fundamental studies necessary for an informed and unbiased historical view remained undone. Already in 1924, Arnold Schering had to admit that "the numerous compositions of Durante have not yet been examined enough to allow making a final judgment" (Schering, 416), and in 1929, Karl Gustav Fellerer finally spoke of an "almost complete ignorance in matters of eighteenth-century [Italian] church music." (Fellerer, 13). What Bukofzer, in his Music of the Baroque Era (1947), had to say about Italian sacred music of the "late Baroque" consists of one brief paragraph within nine pages covering opera seria and opera buffa. The composers mentioned are Lotti (Venice, Dresden) and Caldara (Venice, Vienna), not Leo or Durante (Bukofzer, 247). Forty years later, Grout's History of Western Music (1980, 358) still complains that "for a clearer picture we must look to the Catholic centers in Southern Germany, especially Vienna." Even in a more recent music history textbook for the college market, Mark Evan Bonds' A History of Music in Western Culture (2003), neither Durante nor the Neapolitan School is mentioned, although the name Leonardo Leo appears in a brief list of "some of the leading composers of 18th-century opera." (Bond, 223).

The present situation, however, is not as bad as it may seem when perusing music history textbooks. If we consider all the articles, dissertations and monographs about aspects of Neapolitan church music that have been published since the 1970s, we will be reassured by what has been accomplished. However, much has yet to be done. A most pressing, persistent and challenging issue is the problem of misattributions (Hunt 1983, Carrer and Vitali 1986, Dietz 1988, Atlas

\footnotetext{
${ }^{42}$ See Dietz $(1987,457)$.

43 "Fast darf man sagen: völlige Unkenntnis der Kirchenmusik des 18. Jahrhunderts."
} 
1994). Such cases are quite numerous, and usually not easily sorted out, as in the following example, for which we return to Prague.

Among the undated early eighteenth-century manuscripts of Neapolitan church music found in Prague, a Kyrie-Gloria Mass in Bb major stands out. It is preserved in four sets of vocal and instrumental parts that are attributed to two different composers. Two of the four sets are preserved in the archive of the Knights of the Cross under the titles Kyrie et Glorie à 4 Voci and Missa Jucunda à 4 Voci, respectively. The composer named for both is the same: "Signor Ursini." ${ }^{44}$ The other two sets of this Mass are located in the St. Vitus Cathedral archive, where only one set is attributed to Ursini, here more specifically identified as a Neapolitan maestro: Authore Sig. Ursini, Cappellae Magistro Neapoli. ${ }^{45}$ There can be little doubt that "Ursini" is identical to Gennaro Ursino (1650-c1715), maestro of the Pietà dei Turchini conservatory from 1675 to 1705 , and the SS. Annunziata from 1701 to 1715 in Naples. ${ }^{46}$ The cover of the second set of parts at St. Vitus lists the Mass as Kyrie et Gloria Psallite Regis nostro, and the composer as Del Sig. Durante. ${ }^{47}$ These vocal and instrumental parts were copied in Prague by Joseph Sehling (1710-1756), most likely during the 1730 s or 1740 s. Whoever wrote Durante's name on the cover of the Psallite parts probably was not aware of the Ursini attributions. The stylistic characteristics of the work are too generic to assign it with any certainty to Ursino or early Durante. In the end, the identification of the composer as Ursino or Durante is, in this case, of lesser significance than the fact that the copyist of the "Ursini" at St. Vitus made a decisively informed choice when he gave this Mass with its typical Neapolitan Kyrie-Gloria-only format - the title Missa Neapolitana.

\footnotetext{
${ }^{44}$ Ursini, Mass in Bb major: as Kyrie et Gloria in CZ-Pkřiž: XXXV E 53 (RISM A/II: 550.266.881); Ursini, Mass in Bb major: as Missa Jucunda in CZ-Pkřiž: XXXV E 54 (RISM II/A: 550.266.882).

${ }^{45}$ Ursini, Mass in Bb major: as Missa Neapolitana Kyrie et Gloria in CZ-Pak:: 1334 (RISM II/A: 550.268.590). 


\section{Works Cited}

Abert, Hermann. W. A. Mozart, Leipzig: Breitkopf \& Härtel, 1919, vol. I.

Atlas, Alan (author/ed.). Salve Reginas of G.B. Pergolesi, Pergolesi Complete Edition, Vol. XV, Hillsdale, N.Y.: Pendragon Press, 1994.

Bacciagaluppi, Claudio. "Neapolitan Masses in Central Europe," Early Music: context and ideas II, Kongressbericht Krakau, September 2008, 488-497. Kraków: Uniwersytet Jagielloński, Instytut Muzykologii, 2008.

Bacq, Jacqueline. "Le Fonds Sainte Gudule. Son origine, sa composition, son importance," Louvain: Mémoire de licence à I'Université Catholique de Louvain, 1953.

Beißwenger, Kirsten. Johann Sebastian Bachs Notenbibliothek, Kassel: Bärenreiter, 1991.

Bonds, Mark Warren. A History of Music in Western Culture, Upper Saddle River, N.J.: Prentice Hall, 2003.

Bukofzer, Manfred F. Music in the Baroque Era, New York: Norton, 1947.

Burney, Charles. A General History of Music, London, 1789, Frank Mercer ed., New York: Harcourt \& Brace, 1935, vol. 2.

Buzga, Jaroslaw . "The Vocal Works of Jan Dismas Zelenka," Early Music (April 1981): 177-183.

Carrer, Pinnuccia. Francesco Durante maestro di musica (1684-1755). Genova: Edizione San Marco dei Giustiniani, 2002.

and Carlo Vitali , "Il copista raggiratore. Un apocrifo durantiano conservato preso la British Library," Nuove Revista Italiana XX (1986): 257.

28 Chrysander, Friedrich. G. F. Händel, Leipzig: Breitkopf und Härtel, 1858, 2/1919, vol. I.

Dietz, Hanns-Bertold. "Zur Frage der musikalischen Leitung des Conservatorio di Santa Maria di Loreto in Neapel im 18. Jahrhundert," Die Musikforschung XXV (1972): 419-429.

. "Alte Musik im Schatten Alter Musik," Kongressbericht Internationaler musikwissenschaftlicher Kongress der Gesellschaft für Musikforschung Stuttgart 1985. herausgeg, von Dietrich Berke and Dorothee Hanemann, Band I, 453-460. Kassel: Bärenreiter, 1987.

"Durante, Feo, and Pergolesi: concerning misattributions among their sacred music," Studi Pergolesiani - Pergolesi Studies 2 (1988): 128-143.

"Durante, Francesco," The New Grove Dictionary of Music and Musicians, $2^{\text {nd }}$ ed.,

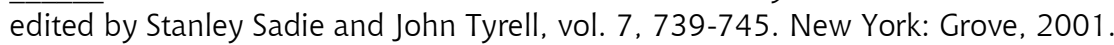

Fabris, Dinko. Music in Seventeenth-Century Naples. Francesco Provenzale (1624-1704), Burlington, VT: Ashgate, 2007.

Fellerer, Karl Gustav. Der Palestrinastil und seine Bedeutung in der vokalen Kirchenmusik des achtzehnten Jahrhunderts, Augsburg: Dr. Benno Filser, 1929.

Ferand, Ernest T. "Embellished Parody Cantatas in the Early $18^{\text {th }}$ Century," Musical Quarterly XLIV (1958): 40-64. 
Fétis, F. J. Biographie Universelle des Musiciens, Brussels: Meline, Cans et Compagnie, 1837.

Fuller-Maitland, John Alexander. The Age of Bach and Handel, Oxford History of Music, vol. IV. London: Oxford University Press, 1904.

Gerber, Ernst Ludwig. Historisch-biographisches Lexicon der Tonkünstler, Leipzig: Johann Gottlob Immanuel Breitkopf, 1790-92, 2 vols.

. Neues historisch-biographisches Lexicon der Tonkünstler, Leipzig: A. Kühnel, 1812-1814, 4 vols.

Griffin. Thomas. Musical References in the Gazzetta di Napoli 1681-1725, Berkeley, CA: Fallen Leaf Press, 1993.

Grout, Donald J. A History of Western Music, New York: Norton, 1960, 3R/1980.

Hanslick, Eduard. Aus dem Tagebuche eines Musikers, Berlin: Allgemeiner Verein für Deutsche Literatur, 3/1892.

Horn, Wolfgang. Die Dresdner Hofkirchenmusik 1720-1745. Studien zu ihren Voraussetzungen und ihrem Repertoire, Kassel: Bärenreiter, 1987.

and Thomas Kohlhase, Zelenka Dokumentation. Quellen und Materialien, 2 vols. Wiesbaden: Breitkopf \& Härtel, 1989.

Hullah, John. A Course of Lectures on the Third or Transitional Period of Musical History, London: Longman, Green, Longman, Roberts \& Green, 1865.

Hunt, Jno L. "The Durante 'Pergolesi' Magnificat: A New Source," Music \& Letters LXIV (1983): 225-228.

Kiesewetter, Raphael Georg. Geschichte der europäisch-abendländischen oder unser heutigen Musik, Leipzig: Breitkopf\&Härtel, 1834; Engl. edit. History of the Modern Music of Western Europe, Robert Müller, transl. London: T. C. Newry, 1848.

Koch, Heinrich Christoph. Musikalisches Lexicon, Frankfurt am Main: August Hermann dem Jüngern, 1802.

Kornmüller, Utto. Lexikon der kirchlichen Tonkunst, Regensburg: Alfred Coppenraths, 2/1891.

Kretzschmar, Hermann. Führer durch den Conzertsaal, Leipzig: A.G. Liebeskind, 1888, vol. II/1, Kirchliche Werke.

Langhans, Wilhelm. Geschichte der Musik des 17., 18., 19. Jahrhunderts. Im chronologischen Anschlusse an die Musikgeschichte von A. W. Ambros, Leipzig: F.E.C. Leuckhart (Constantin Sander), 1882, vol. I.

Larson, Keith A. "Ursino, Gennaro," The New Grove Dictionary of Music and Musicians, $2^{\text {nd }}$ edition, ed. by Stanley Sadie and John Tyrell, vol. 26, 161. New York: Grove, 2001.

Lenaerts, René "The 'Fonds Ste Gudule' in Brussels: An Important Collection of Eighteenth Century Church Music," Acta Musicologica, Vol. 29, Fasc. 4 (Oct.-Dec., 1957): 120-125.

Magaudda, Ausilia. "Giacomo Francesco Milano, Principe d'Ardore, nell'ambito della committenza musicale aristocratica del secolo XVIII," Giacomo Francesco Milano e il ruolo dell'aristocrazia nel patrocinio delle attività musicali nel secolo XVIII, Atti del Convegno 
Internazionale di Studi (Polistena - San Giorgio Morgeto, 12-14 ottobre 1999), a cura di Gaetano Pittarresi, 13-75. Reggio Calabria: Laruffa Editore, 2001.

Mendel, Herman. Musikalisches Conversations-Lexicon, Berlin: R. Oppenheim, 1873, vol. III.

Pitarresi, Gaetano. "I caratteri stilistici della produzione di Giacomo Francesco Milano, principe musicista," Giacomo Francesc Milano ed il ruolo dell' aristocrazia nel patrocini delle attività musicali nel secolo XVIII," Convegno Internazionale di Studi (Polistena-San Giorgio Morgeto, 12-14 ottobre 1999), A cura di Gaetano Pitarresi, 77-116. Reggio Calabria: Laruffa Editore, 2001.

Reichhardt, Johann Friedrich. Musikalisches Kunstmagazin, Berlin: 1791, vol. 2.

Renton, Barbara Anne. "The Musical Culture of Eighteenth-Century Bohemia, with special emphasis on the music inventories of the Osek and the Knights of the Cross," Ph.D. diss., City University of New York, 1990; Ann Arbor: UMI, 1990.

Riedel, Friedrich W. Kirchenmusik am Hofe Karls VI. (1711-1740). Untersuchungen zum Verhältnis von Zeremoniell und musikalischen Stil im Barockzeitalter, München-Salzburg: Emil Katzbichler, 1977.

RISM-A/II: International Inventory of Musical Sources after1600; Online Database (http:// w.w.w. nisc.com).

Rousseau, Jean Jacques. Dictionaire de Musique, Paris: Veuve Duchesne, 1768.

Schering, Arnold. Handbuch der Musikgeschichte bis zum Ausgang des achtzehnten Jahrhunderts, Leipzig: Breitkopf \& Härtel, 1923.

Schilling, Gustav. Encyclopädie der gesamten musikalischen Wissenschaften, Stuttgart: F.H. Köhler, 1835.

Schmieder, Wolfgang. Bach Werke Verzeichnis, Leipzig: Breitkopf \& Härtel, 1956.

30 Scholes, Percy A. Dr. Burney's Musical Tours in Europe, vol. 1, An Eighteenth-Century Musical Tour in France and Italy, London: Oxford University Press 1959.

Stefan, Jiři. Ecclesia metropolitana Pragensis catalogus (etc), Praha: Supraphon, 1983-1985, 2 vols.

Walker, Frank. "Durante, Francesco." Grove's Dictionary of Music and Musicians, 5th ed., Eric Blom ed., vol. II: 819-821. London: Macmillan, 1954.

Hanns-Bertold Dietz: hbd@mail.utexas.edu

Recebido e aprovado em 19 de setembro de 2009 